удК 338:658.15

\title{
УДОСКОНАЛЕННЯ СИСТЕМИ УПРАВЛІННЯ ОБОРОТНИМИ АКТИВАМИ ПІДПРИЕМСТВА НА БАЗІ КОНЦЕПЦІї JUST IN TIME
}

\section{IMPROVING THE CURRENT ASSETS MANAGEMENT SYSTEM OF THE ENTERPRISE BASED ON THE CONCEPT OF JUST IN TIME}

\author{
Чуприна Христина Миколаївна \\ доктор економічних наук, доцент, \\ Київський національний університет будівництва і архітектури \\ ORCID: https://orcid.org/0000-0001-5518-3607 \\ Валяев Олександр Васильович \\ аспірант, \\ Київський національний університет будівництва і архітектури \\ ORCID: https://orcid.org/0000-0003-2039-6084 \\ Деркач Андрій Євгенійович \\ аспірант, \\ Київський національний університет будівництва і архітектури \\ ORCID: https://orcid.org/0000-0001-5225-0018 \\ Chupryna Khrystyna, Valiaiev Oleksandr, Derkach Andrii \\ Kyiv National University Construction and Architecture
}

\begin{abstract}
В умовах цисрровізації економіки українські підприємства вимушені змінювати свій стратегічний курс на інтеграцію в світовий економічний простір, при реалізації якого виникають питання, пов'язані з необхідністю розробки та застосування нових технологій фінансового менеджменту підприємств, частиною якого є система управління оборотними активами. При фрормуванні сучасної системи управління цієї складової активів підприємств залишається багато невирішених проблем, обумовлених недостатнім розвитком основних положень системи управління найменш ліквідними активами підприємства такими як незавершене виробництво, готова продукція, виробничі запаси. При цьому, стан і ефективність використання виробничих запасів, як самої значної частини оборотного капіталу - $є$ одним з основних умов успішної діяльності підприємства. Удосконалення фрінансового механізму управління оборотними активами підприємства можливе за рахунок використання концепції менеджменту, спрямованих на підвищення продуктивності за рахунок скорочення тривалості виробничого процесу і запобігання та скорочення всіх видів втрат. Однією з таких концепцій є бережливе виробництво. В системі «бережливого виробництва» застосовуються близько 25 різних інструментів. Одним 3 найвідоміших і дієвих виступає система «точно вчасно» (в перекладі з англ. Just-in-time), що припускає наявність мінімальних запасів або їх відсутність, тобто коли ресурси необхідного виду надходять на виробничу лінію точно в необхідному розмірі та в потрібний момент. Дана концепція визначає безліч негативних фракторів, що знижують фрінансову стійкість підприємства і під впливом яких знаходиться господарська діяльність підприємств в умовах цифровізації економіки. У даній статті вивчені такі оборотні кошти як виробничі запаси 3 точки зору їх фрормування і ефрективного використання та сфрормовано ефективний механізм управління оборотнім капіталом підприємства на базі концепції јust-in-time.
\end{abstract}

Ключові слова: оборотні активи, механізм управління запасами, концепція Just in Time.

В условиях цифровизации экономики украинские предприятия вынуждены менять свой стратегический курс на интеграцию в мировое экономическое пространство, при реализации которого возникают вопросы, связанные с необходимостью разработки и применения новых технологий фринансового менеджмента предприятий, частью которого является система управления оборотными активами. При фрормировании современной системы управления этой составляющей активов предприятий остается много нерешенных проблем, обусловленных развитием основных положений системы управления наименее ликвидными актива- 
ми предприятия такими как незавершенное производство, готовая продукция, производственные запасы. При этом, состояние и эффрективность использования производственных запасов, как самой значительной части оборотного капитала - является одним из основных условий успешной деятельности предприятия. Совершенствование фринансового механизма управления оборотными активами предприятия возможно за счет использования концепции менеджмента, направленных на повышение производительности за счет сокращения длительности производственного процесса и предотвращения и сокращения всех видов потерь. Одной из таких концепций является бережливое производство. В системе «бережливого производства» применяются около 25 различных инструментов. Одним из самых известных и действенных выступает система «точно вовремя» (в переводе с англ. Just-in-time), что предполагает наличие минимальных запасов или их отсутствие, то есть когда ресурсы необходимого вида поступают на производственную линию точно в необходимом размере и в нужный момент. Данная концепция определяет множество негативных фракторов, снижающих фринансовую устойчивость предприятия и под влиянием которых находится хозяйственная деятельность предприятий в условиях цифровизации экономик. В данной статье изучены такие оборотные средства как производственные запасы с точки зрения их формирования и эффеективного использования и сформирован эффрективный механизм управления обратимым капиталом предприятия на базе концепции јust-in-time.

Ключевые слова: оборотные активы, механизм управления запасами, концепция Just in Time.

In the context of digitalization of the economy, Ukrainian enterprises are forced to change their strategic course to integrate into the world economic space, the implementation of which raises issues related to the need to develop and apply new technologies of financial management of enterprises, part of which is current assets management system. In the formation of a modern management system of this component of enterprise assets there are many unresolved problems due to insufficient development of the main provisions of the management system of the least liquid assets of the enterprise such as work in progress, finished goods, inventories. At the same time, the state and efficiency of the use of inventories, as the most significant part of working capital - is one of the main conditions for successful operation of the enterprise. Improving the financial mechanism for managing current assets of the enterprise is possible through the use of management concepts aimed at increasing productivity by reducing the duration of the production process and preventing and reducing all types of losses. One such concept is lean manufacturing. About 25 different tools are used in the "lean production" system. One of the most famous and effective is the system "just in time", which assumes the presence of minimum stocks or their absence, ie when the resources of the desired type arrive at the production line exactly in the right size and at the right time. This concept identifies many negative factors that reduce the financial stability of the enterprise and under the influence of which is the economic activity of enterprises in terms of digitalization of economies. This article examines such working capital as inventories in terms of their formation and efficient use and formed an effective mechanism for working capital management of the enterprise based on the concept of just-in-time. An effective mechanism for working capital management of the enterprise based on the concept of just-in-time has been developed. Elements of this mechanism are formed taking into account modern factors of influence and features of branch affiliation, consider influence of external environment, potential of formation of financial resources, rates of economic development, and other parameters of functioning of the enterprise. The practical application of the proposed mechanism will provide an opportunity to comprehensively investigate, manage and increase the efficiency of current assets of the enterprise, which will increase the level of its solvency and liquidity in general.

Keywords: current assets, inventory management mechanism, Just in Time concept.

Постановка проблеми. Цифровізація економіки України, розвиток ринкових відносин визначає нові умови фуункціонування більшості вітчизняних підприємств, сучасний стан яких свідчить про недостатню ефективність управлінських рішень у частині менеджменту оборотними активами, що проявляється через неоптимальність їх складу та структури і взаємоузгодженості 3 джерелами фрінансування. Інфрляція, неплатежі й інші кризові явища змушують підприємства змінювати свою політику по відношенню до виробничих запасів, шукати нові джерела поповнення, вивчати проблему есрективності їх використання. Як наслідок питання управління запасами став розглядатися, в тому числі і в контексті ефективної роботи підприємств, а всі можливі способи раціонального витрачання коштів, одним з яких є визначення оптимальної величини виробничих запасів, набувають все більшої значущості. Тому, при удосконаленні механізму управління оборотними активами на підприємстві як важливого напрямку фрінансової політики організації, в умовах цисрровізації економіки, доцільно було б застосувати ефективний механізм управління запасами на базі концепції Just in Time.

Мета даної статі полягає в удосконаленні орінансового механізму управління оборотними активами підприємства шляхом трансформації системи управління запасами згідно концепції Just in Time.

Аналіз останніх досліджень та публікацій. Аналіз економічної сутності оборотних активів дозволив сорормулювати висновок про те, що питання їх природи, незважаючи 
на великий обсяг наукових робіт, все ще $\epsilon$ дискусійним в контексті застосування концепції «бережливого виробництва».

Питання орормування і кругообігу оборотних коштів були предметом дослідження таких зарубіжних вчених, як І.О. Бланк, Брейли Р., Бригхем Ю., Вестресрилд Р., Єрмолович Л.Л., Гелбрейт Дж.К., Суша Г.З., Маршалл А., Норт Д., Онисько С.М., Крейнина М.Н., Крамаренко Г.О. та ін.

Вивченням питання управління запасами, як частини системи оборотних активів науковці займаються досить давно. Наукові праці, в області вивчення ефеективності роботи системи управління запасами 3 метою безперебійного забезпечення запасами підприємств, зустрічаються у всіх сфрерах господарської діяльності. Алгоритми управління запасами ґрунтуються на класичних системах управління запасами і на їх модисрікаціях. У розроблених методиках управління запасами в вузькоспеціалізованих сфрерах можна звернути увагу на облік параметрів, які не властиві іншим сорерам застосування.

Питанням формування систем управління запасами, матеріально-технічного постачання підприємств і вирішення виникаючих при цьому логістичних проблем приділено увагу в працях наукової вітчизняної та зарубіжної літератури таких авторів, як Анікін Б.А., Гаджинский А.М., Іванов Д.А., Сергєєв В.І., Стерлигова А.Н., Дибська В.В., Бауерсокс Д.Дж., Уотерс Д., Сток Дж.Р., Ламберт Д.М.

Крім того, в останні роки видається і перекладна література з логістики, що включає розділ управління запасами або повністю присвячена питанню управління запасами. Прикладом можуть служити роботи Д.Дж. Бауерсокс і Д.Дж. Клосса, М. Крістофрера, М. Ліндерс, Дж. Шрайбфедера та ін.

Розробкою і концепції «Just-in-time», аналізом і вирішенням проблем її практичного застосування займалися Тайіті Воно, Пітеркін С.В., Вейдер М., Вумек Джеймс П., Джонс Даніел Т., Гарєєв Т.Ф. і багато інших авторів.

Аналіз робіт в області дослідження ефективності роботи системи управління запасами на виробничих підприємствах дозволяє зробити висновок про відсутність системного підходу до методики прогнозу і розрахунку параметрів, необхідних для функціонування системи управління запасами в умовах цифрровізації економіки. Як правило, не враховані всі необхідні критерії розрахунку чи враховані тільки характерні для конкретного виду діяльності. Таким чином, питання розробки меха- нізму управління запасами, як пріоритетної компоненти системи управління оборотними активами в загальній системі управління фрінансами підприємства, з урахуванням особливостей підприємства і на базі концепції just-in-time - актуальне для розвитку виробничих підприємств в умовах цисрровізації економіки.

Виклад основного матеріалу. В загальній системі управління фрінансами підприємства в умовах цифрровізації економіки, виникають питання, пов'язані з розробкою та застосуванням нових технологій фрінансового менеджменту підприємств, частиною якого $€$ система управління оборотними активами. Визначення обсягу і структури оборотних активів, джерел їх покриття і співвідношення між ними, достатнього для забезпечення довгострокової виробничої і ефективної фрінансової діяльності підприємства $€$ цільовою установкою політики управління оборотним капіталом. При виборі політики управління оборотними активами підприємства необхідно враховувати різноманітність об'єктів управління: сировина і матеріали, запаси, незавершене виробництво, готова продукція, грошові кошти, дебіторська заборгованість, інші оборотні активи.

Типи політики та методологічні підходи до управління різними видами оборотних активів організації можуть бути різними. Економічні методи грають провідну роль в управлінні оборотними активами підприємства, оскільки вони дають математичні маркери, точні цілі, з якими досить легко порівнювати отримані результати.

Загальні етапи роботи з управління оборотними активами підприємства наступні: аналіз залишків, аналіз руху, визначення оптимального рівня, прогнозування і планування, порівняння фактичного результату з прогнозом.

Для управління оборотними активами підприємства застосовують такі розрахункові методи аналізу, як: аналітичний, розрахунок коесріцієнтів, прямий рахунок (нормування на основі розрахункових показників величини запасів). Методи управління оборотними активами підприємства досить різноманітні. Організація може вибрати при створенні своєї політики управління ті методики, які підходять саме їй.

Та на практиці залишаються відставання в питаннях вдосконалення організаційних i управлінських процесів, обумовлені недостатнім розвитком основних положень системи управління найменш ліквідними активами 
підприємства такими як виробничі запаси, незавершене виробництво, готова продукція. При цьому, стан і ефеективність використання виробничих запасів, як самої значної частини оборотного капіталу - $€$ одним 3 основних умов успішної діяльності підприємства.

Важливим напрямом удосконалення фрункціонування оборотного капіталу та підвищення ефективності управління ним в умовах трансфрормації економіки України є комплекс заходів, пов'язаних з підвищенням рівня технологічності нормування і планування оборотного капіталу. У даному напряму нами запропоновано механізм управління оборотнім капіталом підприємства на базі концепції just-in-time, яка сприятиме оптимізації орінансових потоків та підвищенню едрективності фоункціонування підприємства в цілому (рис. 1). Механізм містить елементи активів та організаційну, процесну, інформаційну та фрункціональну підсистеми, кожна 3 них відповідає певній стадії виробничого циклу та доповнює іншу. Для підвищення ефективності фрункціонування сфрормованого механізм управління оборотнім капіталом підприємства на базі концепції just-in-time необхідно враховувати вплив на неї елементів організаційної складової. Забезпечення ефективності всіх сорер діяльності підприємства пов'язане з оборотними активами, продуктивністю їх використання та обсягом, який прямо залежить від обсягу господарської діяльності підприємства.

При розгляді процесної частини сорормованого механізму, особлива увага приділена управлінню елементами оборотного капіталу, та виділено три основні групи кожна з яких, маючи свою специфріку й інструментарій, поєднана з іншими взаємним впливом на кінцевий результат обороту, а саме: управління грошовими коштами, управління дебіторською заборгованістю, управління запасами.

Що стосується управління грошовими коштами, то тут найважливішим моментом $\epsilon$ розрахунок мінімально необхідної суми грошових активів. Його пропонується будувати на плануванні грошового потоку за поточними господарськими операціями і обсягом витрачання активів по них в майбутньому періоді.

Наступним 3 найважливіших питань управління оборотним капіталом $€$ оцінка реального стану дебіторської заборгованості, тобто оцінка вірогідності безнадійних боргів, яка ведеться окремо по групах дебіторської заборгованості. При управлінні дебіторською заборгованістю авторами пропонується контролювати стан розрахунків з покупцями за простроченою заборгованістю; орієнтува- тися на більше число покупців, щоб понизити ризик несплати одним або декількома крупними покупцями; стежити за співвідношенням дебіторської і кредиторської заборгованості; надавати знижки при достроковій оплаті.

- Управління запасами. Найбільша увага приділяється управлінню запасами, як фрункціональній діяльності підприємства, мета якої - довести загальну суму щорічних витрат на утримування запасів до мінімуму за умови задовільного обслуговування клієнтів. Важливість управління запасами пояснюється, насамперед, тим, що виробництво - це потік матеріальних ресурсів через процес, який змінює фрорму цих матеріалів, перетворюючи їх у готову продукцію. В період циорровізації економіки та впровадження технології Індустрія 4.0. власники підприємств освідомили важливість даного питання, і починають особливу увагу приділяти управлінню витратами на зберігання, складування, утилізації невикористаних запасів, напівфрабрикатів та запобіганню браку.

Створення та зберігання запасів потребують значних витрат, тому важливо керувати запасами, щоб зазначені витрати були мінімальними та забезпечувався той рівень виробництва, обслуговування та задоволення запитів клієнтів, до якого прагне підприємство.

Для ефрективного фрункціонування наведеного механізм управління оборотнім капіталом підприємства на базі концепції just-in-time необхідно детально дослідити всі елементи управління та ссреру їх обігу. Чітко окреслити різницю між концепцією «just-in-time» і традиційним менеджментом. Це дасть можливість визначити елементи правління у фрункціональній складовій, а саме методи мотивації, способи контролю та організації.

Сучасна концепція менеджменту, створена на підвищенні продуктивності за рахунок скорочення тривалості виробничого процесу та скорочення всіх видових витрат, що виникають в процесі, $€$ «безпечне виробництво», в системі якого застосовується близько 25 різних інструментів. Однім 3 найвідоміших та найефрективніших виступів системи «вчасно» (у перекладі з англ. Just-in-time), передбачається наявність мінімальних запасів або їх відсутність - ресурси, необхідні видачі, що подаються на виробничу лінію точно в необхідному розмірі та в потрібний момент.

3 точки зору традиційного підходу до організації роботи передбачається, що запаси - це важливий елемент всієї системи, гарантований відсутність збору при виконанні операцій. Сучасні же концепції менеджменту скорочу- 


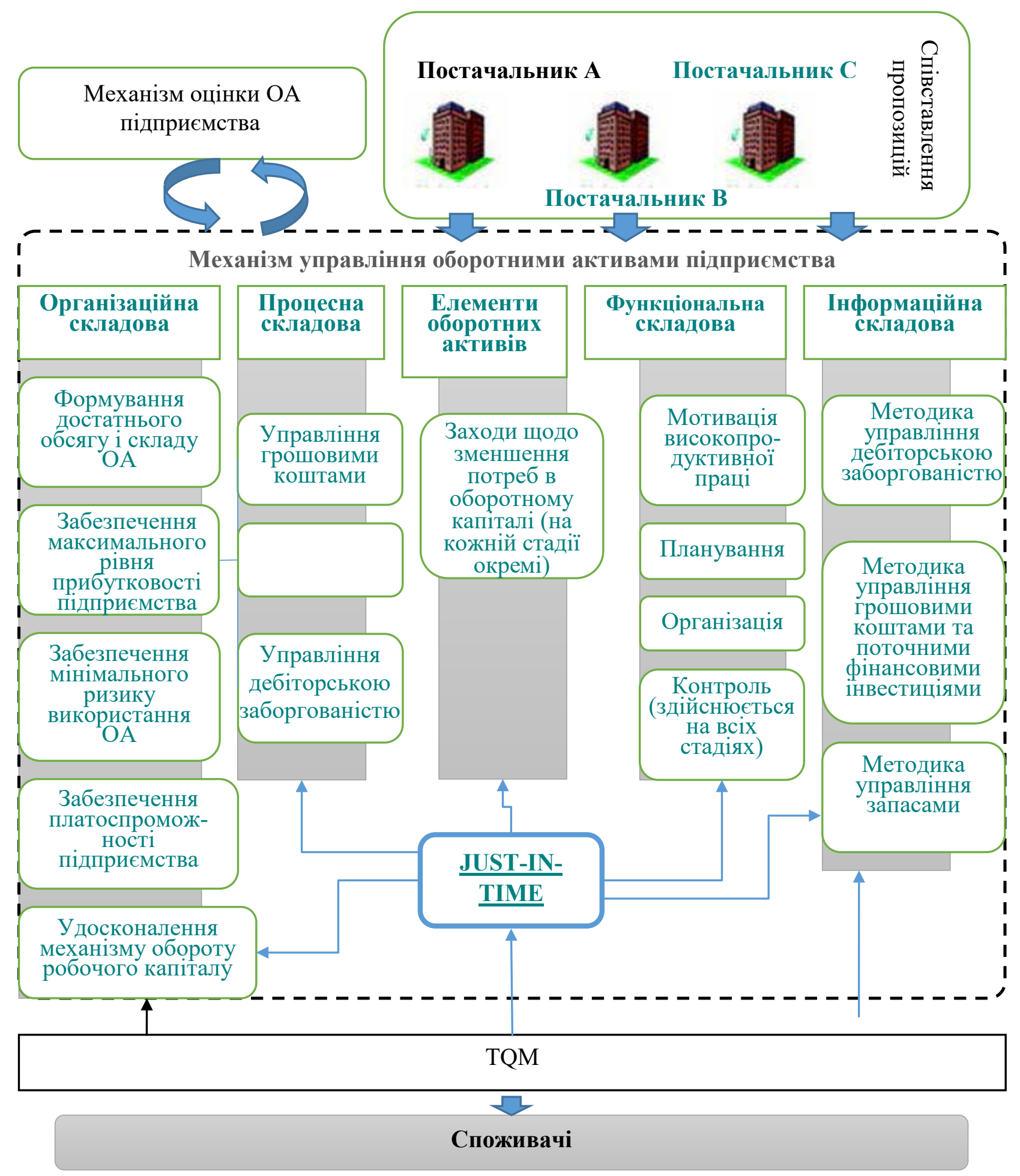

Рис. 1. Ефективний механізм управління оборотнім капіталом підприємства на базі концепції just-in-time

ють обсяги запасів, трансформуючи основну грасріку таким чином, щоб забезпечити більш близьке відповідність між встановленими матеріалами та спробами на них, за цього певного страхового запасу все це забезпечується у випадку непередбачених проблем. При цьому менший запас нам потрібен, якщо буде забезпечений ступінь відповідності між запитом та поставкою. А прийти до нульового запасу можна за допомогою усунення абсолютно всіх невідповідностей між поставками та запитом. Сучасні технології just-in-time i логістичні системи стали більш інтегрованими і комбінуються з різних варіантів логіс- 


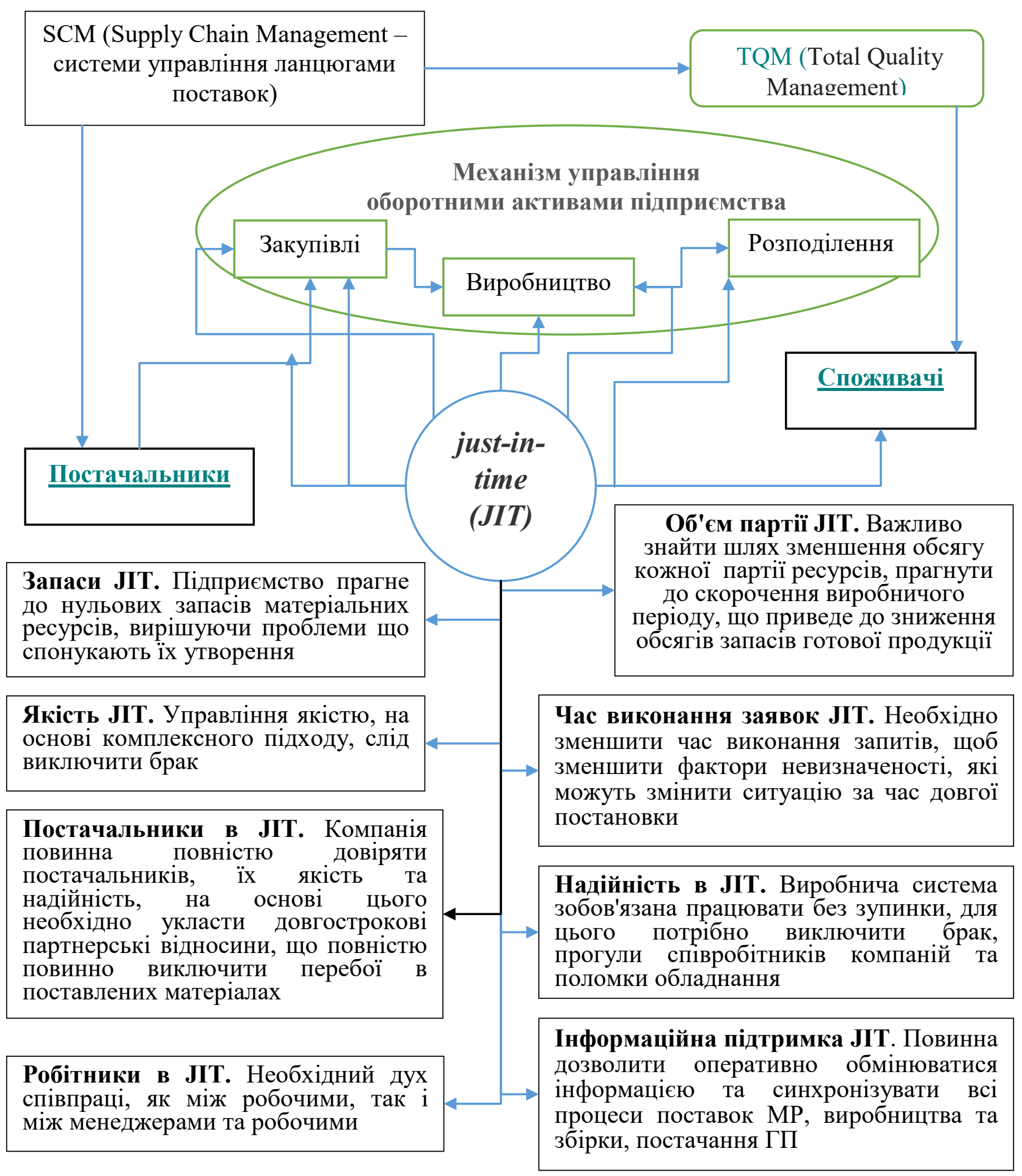

Рис. 2. Модель інтеграції технології just-in-time в систему управління оборотними активами підприємства

тичних виробничих концепцій і розподільних систем, таких як системи, що мінімізують запаси в логістичних каналах, логістичні системи швидкого перемикання, вирівнювання рівня запасів, групові технології, превентивне гнучке автоматизоване виробництво, сучасні логістичні системи загального статистичного контролю і управління циклами якості продук- ції. Основні складові концепції "just-in-time" представлені на рис. 2.

Таким чином, базуючись на рис. 2, можна зробити висновок, що потенційні переваги системи just-in-time численні. До основних 3 них можна віднести наступні:

- іï застосування призводить до зменшення рівня запасів, що означає менше вкла- 
день капіталу в товарно-матеріальні запаси. Оскільки в цій системі потрібно мати в наявності для негайного використання мінімальну кількість матеріалів, то істотно знижується загальний рівень запасів.

- в умовах цисрровізації економіки застосування системи just-in-time мають місце скорочення циклу виконання замовлення і зростання надійності його виконання. Що в свою чергу сприяє суттєвому зменшенню потреби в резервному запасі, який представляє собою додаткові товарні одиниці запасів, які зберігаються щоб уникнути можливого дефіциту. Грасрік виробництва в рамках планово виробничої перспективи також скорочується. Це дозволяє виграти час, необхідний для того, щоб відреагувати на зміни кон'юнктури ринку. Виробництво продукції невеликими партіями також сприяє досягненню більшої гнучкості.

- при застосуванні цієї системи відзначається поліпшення якості виробництва. Коли замовлену кількість продукції невелика, джерело проблем з якістю легко виявляється і коригування вносяться негайно. У цих умовах у працівників спостерігається більше розуміння значення якості, що веде до поліпшення якості виробництва на робочих місцях.

До інших переваг системи just-in-time можна віднести: зменшення капітальних витрат на утримання складських приміщень для запасів матеріалів і готової продукції; зниження ризику морального застаріння запасів; зниження втрат від браку і зменшення витрат на переробку; зменшення обсягу документації.

Використання запропонованої моделі інтеграції технологіï just-in-time в механізм управління оборотними активами вітчизняних під- приємств забезпечить потреби керівників у прийнятті ефективних управлінських рішень про вид, ціну, собівартості, склад і шляхи збуту продукції та сприятиме подальшому вдосконаленню виробничої і комерційної діяльності підприємства, підвищення рівня його платоспроможності та ліквідності в цілому.

Висновки. Проблема управління оборотними активами підприємства актуальна для всіх підприємств незалежно від умов їх господарювання, i, особливо, в теперішніх умовах цифрровізації економіки, коли вплив фракторів, що впливають на результати фрінансово-господарської діяльності постійно змінюються, і потрібні інструменти не тільки для прогнозування і планування оборотних активів і фрінансових потоків, а й для управління ними.

Поєднання всіх складових у запропонованому в статті ефрективному механізмі управління оборотним капіталом підприємства на базі концепції just-in-time дає можливість комплексно досліджувати та управляти елементами оборотного капіталу та підприємства в цілому. Кожна складова даного механізму формується з урахуванням сучасних чинників впливу та особливості галузевої приналежності, зміни фракторів зовнішнього середовища, потенціалу фрормування фрінансових ресурсів, темпів економічного розвитку, фрорм організації виробничої й фрінансової діяльності, фрінансового стану й інших параметрів фуункціонування підприємства. Практичне застосування запропонованого механізму дозволить підвищувати ефективність використання оборотних активів підприємства та призведе до підвищення рівня його платоспроможності та ліквідності в цілому.

\section{СПИСОК ВИКОРИСТАНИХ ДЖЕРЕЛ:}

1. Баранова В.Г., Гоцуляк С.М. Теоретичні засади управління оборотним капіталом. Вісник соціальноекономічних досліджень. 2008. № 30. С. 32-36.

2. Бодаренко О.С. Методологічні основи управління оборотними активами підприємств. Інвестиції практика та досвід. 2008. № 4. С. 40-44.

3. Кодацький В.П. Шляхи есрективного управління оборотними активами промислових підприємств. Актуальні проблеми економіки. 2010. № 4. С. 271-274.

4. Ящук Д.Л. Дослідження методології управління оборотними активами підприємств в умовах кризи. URL: http://archive.nbuv.gov.ua/portal/natural/Vetp/2010_32/10ydlsof.pdf

5. Чобіток В.І., Пятилокотова К.С. Управління оборотними активами підприємства: теоретичний аспект. URL: http://archive.nbuv.gov.ua/portal/natural/ Vetp/2013_41/13cvieic.pdf

6. Єпіранова І.Ю., Джеджула В.В. Фінансовий аналіз та звітність : практикум. Вінниця, 2017. 143 с.

7. Управление производством. «Философия just-in-time». URL: http://www.artkis.ru/article.php

8. Система «Бережливого производства» - это концентрация лучшего опыта. URL: http://www. consultperson.asp.htm

9. «Точно вовремя» для рабочих. Институт комплексных стратегических исследований. 2007. 122 с

10. Чуприна Х.М., Бородавко М.В., Гавриков Д.О., Грабчак Д.В. Економіко-математична модель оцінки економічної стійкості будівельного підприємства в умовах цифровізації економіки. Бізнес-навігатор. 2020. № 1(57). C. 176-183. 
11. Чуприна Х.М., Бородавка М.В., Грабчак Д.В. Структурно-когнітивне моделювання на основі інтелектуалізації процесів адміністрування будівельними підприємствами. Формування ринкових відносин в Україні : 3б. наук. праць. Київ : ДНДІ інформатизації та економіки, 2020. № 5(228). С. 89-98.

12. Чуприна Х.М., Чуприна Ю.А., Бородавко М.В., Гавріков Д.О. Стратегії реконфрігурації бізнес-процесів будівельних підприємств. Управління розвитком складних систем. 2020. № 41. С. 169-174.

13. Зви Боди, Роберт Мертон Финансы. Москва : «Вильямс», 2007. 592 с.

14. Ван Хорн Дж. К., Вахович Дж. М. (мл.) Основи фринансового менеджмента. 12-е изд. Москва : Вильямс, 2006. 1232 c.

15. Васелевський М. та ін. Економіка логістичних систем : Монографрія / За наук. ред. Є. Крикавського та С. Кубіва. Львів : В-во Національного університету «Львівська політехніка», 2008. 596 с.

16. Фишер А. Методы выделения групп в АBC-XYZ анализе. Логистика и Управление. 2008. № 1.

17. Тимошенко А. В. Системи управління запасами. Справочник экономиста. 2008. № 9. С. 53-57.

\section{REFERENCES:}

1. Baranova V.G., Gotsulyak S.M. (2008) Theoretical ambushes of the management of the werewolf capital. Bulletin of Social and Economic Research, no. 30, pp. 32-36.

2. Bodarenko O.S. (2008) Methodological bases of management of circulating assets of enterprises. Investments practice that dosvid, no. 4, pp. 40-44.

3. Kodatskiy V.P. (2010) Shlyakhi effective management of circulating assets of industrial enterprises. Actual problems of economy, no. 4, pp. 271-274.

4. Yashchuk D.L. Preliminary methodology for managing the circulating assets of enterprises in the minds of the crisis. Available at: http://archive.nbuv.gov.ua/portal/natural/Vetp/2010_32/10ydlsof.pdf

5. Chobitok V.I., Pyatilokotova K.S. (2013) Werewolf management enterprise assets: theoretical aspect. Available at: http://archive.nbuv.gov.ua/portal/natural/Vetp/2013_41/13cvieic.pdf

6. Epifanova I.Yu., Dzhedzhula V.V. (2017) Finance analysis and reliability: workshop. Vinnytsia, 143 p. (in Ukrainian)

7. Production management. "Philosophy just-in-time". Available at: http://www.artkis.ru/article.php

8. The Lean Manufacturing system is a concentration of best practices. Available at: http://www.consultperson.asp.htm

9. "Just in time" for workers. Institute for Comprehensive Strategic Studies (2007). 122 p.

10. Chupryna Kh.M., Borodavko M.V., Gavrikov D.O., Grabchak D.V. (2020) Economic and mathematical model for assessing the economic efficiency of the business enterprise in the minds of the digitalization of the economy. Business Navigator, no. 1(57), pp. 176-183. (in Ukrainian)

11. Chupryna Kh.M., Wart M.V., Grabchak D.V. (2020) Structural and cognitive modeling based on the intellectualization of administrative processes by educational enterprises. Formation of Rinkovy Vidnosin in Ukraine: zb. sciences. good. Kiev: DNDI informatization and economy, no. 5(228), pp. 89-98. (in Ukrainian)

12. Chupryna Kh.M., Chupryna Yu.A., Borodavko M.V., Gavrikov D.O. (2020) Strategies for reconfiguring business processes in educational enterprises. Management of the development of folding systems, no. 41, pp. 169-174. (in Ukrainian)

13.Zvi Bodie, Robert Merton (2007) Finance. Moscow: "Williams", 592 p. (in Russian)

14.Van Horn J.K., Vakhovich J.M. (Jr.) (2006) Fundamentals of financial management. 12th ed. Moscow: Williams, 1232 p. (in Russian)

15. Vaselevsky M. and in. Economics of Logistic Systems: Monografiya (2008) (eds. E. Krikavsky and S. Kubiva). Lviv: In the National University of Lviv Polytechnic, $596 \mathrm{p}$.

16. Fisher A. (2008) Methods for identifying groups in ABC-XYZ analysis. "Logistics and Management", no. 1.

17. Timoshenko A.V. (2008) Systems of inventory management. Economist's Handbook, no. 9, pp. 53-57. 